\title{
Gender and Toys in Early Childhood Education
}

\author{
Suci Ramdaeni ${ }^{1, *}$ Vina Adriany ${ }^{1}$ Hani Yulindrasari ${ }^{1}$ \\ ${ }^{1}$ Department of Early Childhood Education, Universitas Pendidikan Indonesia, Bandung, Indonesia \\ ${ }^{*}$ Corresponding author. Email: suciramdaeni@student.upi.edu
}

\begin{abstract}
This paper aims to explore how children construct gender through toys. Using a post-structuralist perspective, we look at how power relations are intertwined in children's play activities that strengthen gender binary through toys. This study was an ethnographic study conducted in Bandung, Indonesia. The findings show that toys used as learning media are often gendered. Both children and teachers reinforce gender stereotypes in selecting toys for boys and girls which preserve gender inequality in early childhood education. Based on the findings, we recommend that educators in early childhood education to be more gender aware to be able to provide equal opportunity for boys and girls to learn skills that are important for the children's development.

Keywords: Gender, early childhood education, post-structuralism, toy
\end{abstract}

\section{INTRODUCTION}

Gender issues often go unnoticed in early childhood education curriculum. The lack of attention on gender issues is supported by an understanding that gender issues are not too important in early childhood education (ECE) (MacNaughton, 2000). This is because gender often refers to biological determinism that distinguishes men and women fundamentally (Osgood, 2006). Through the lens of biological determinism everything about gender differences is considered as natural (Coleman \& Hong, 2008). As a consequence, gender differences are normalised. Thus, the inequality between men and women exists (Kilvington \& Wood, 2016).

The 'natural' ideas of gender are strengthened by the developmentalism discourse in early childhood development, which sees child's development and childhood as universal (Walkerdine, 1993). Thus, gender issue in early childhood remains unchallenged. The strong developmentalism discourse is often shown through an understanding that early childhood has parallel stages and development tasks (Burman, 2008). Young children are often considered innocent and not yet able to understand crucial issues including gender (Adriany, 2019a; MacNaughton, 2000). Nevertheless, there are many studies which have proven that young children are an active agent that can construct, negotiate, and deconstruct gender construction (MacNaughton, 2000, 2005; Adriany, 2019a; Martin, 2011; Paechter, 2007).

The dominant gender discourse in the society affects boys and girls' understanding about how to be boys and how to be girls, which in turn will reinforce the stereotype of gender. For example, children's preference of toys often reinforces gender stereotypes (Adriany, 2019a; Kilvington $\&$ Wood, 2016). Boys often reinforce their masculinity through "masculine" associated toys such as superhero characters, battles, football, lego and blocks, while girls reinforce traditional femininity through Barbie dolls, or toys related to domestic chores (Adriany, 2019a; Early et al, 2010; Martin, 2011; Wood, Desmarais \& Gugula, 2002).

The choice of different toys between boys and girls is often reinforced by adults. Even parents give different encouragement to boys and girls by providing toys that are consistent to gender stereotypes so that toys are very gendered (Paechter, 2006; Wood, Desmarais, \& Gugula, 2002; Francis, 2010). As for parents who want to challenge gender stereotypes, they worry that their children will not be accepted in their social environment (Kilvington \& Wood, 2016).

Gendered toy selection that segregate boys and girls is often shown by the teachers (Adriany \& Warin, 2014). Teachers often criticize children who plays with crossgendered toys (Freeman, 2007). Adriany \& Warin (2014) show that in an Indonesian context, teachers associated boys who liked Barbie dolls with homosexuality. Similar to it, a research study in a Western context by Paechter (2006; 2007) also shows that boys who are attracted to stereotypically girls' toys place their masculinities open for scrutiny by their peers. Teachers are often unaware that they have perpetuated gender segregation and threat the children based on the children's sex identity (Chapman, 2016).

Compulsory society approval on gender has limited what kind of play the boys and girls can have. Boys do not have the access to stereotypically feminine play space and with toys that are associated with femininity. On the other hand, girls have limited access to stereotypically masculine toys. Consequently, boys and girls often have different experiences of play (Martin, 2011). Fabes, Hanish and 
Martin (2003) argue that different experiences between boys and girls will affect children's development.

There have been many studies examining how toy selection reinforces gender inequality. Some of these studies are often carried out in the global North (Macnaughton, 2000; Freeman, 2007: Martin, 2011; Cherney et al., 2003; Wood, Desmarais, \& Gugula, 2002). As for research conducted in Indonesia by Adriany (2019a) shows that children reinforce gender inequality through Barbie and princess discourse, where boys get an exception to access the play. Boys construct hegemonic masculinity by avoiding Barbie or everything that are related to girls or femininity. Research about gender and selection of play in Indonesian early childhood context is very limited. So far, we found a literature review based article about gender and toy selection (Hana, 2018) published in a local Indonesian journal. To fill the gap this research investigated how the gendered selection of toys were exercised in the context of early childhood education. Through the lens of post-structuralism, we challenge the dominant gender discourse and unequal power relations in children's plays and propose a gender flexible playing space and selection of toys in an ECE context.

\section{THEORETICAL FRAMEWORK}

Feminist post-structuralism is a perspective that observes power relations in the production of knowledge through language and discourse (MacNaughton, 2000). Foucault (1982) explains that power is embedded in ideological structures that control subjectivities and determine submission and subjugation. Power operates in a social environment, not owned by individuals, but operates in all relationships and is expressed through discourse (Blaise, 2009) in the form of ideas that are built socially and historically (Ryan, 2005).

Sumsion (2005) analyses discourses to understand and assess children's voice by observing teacher's understanding in the context of historical and social culture. Discourse is more than just ideas; it operates through language. Children are born in pre-existing discourse and when they learn languages they learn discourse (MacNaughton \& Davies, 2009).

Language is words and concepts that change their meanings and definitions when used in different discourses, where these discourses often have multiple meanings (Adriany, 2013; Smith, 2014). For example, Smith explains how the discourse of salvation, the concept of "strangers" is considered a threat, dangerous, but in different discourses foreigners are considered as people who allow us to know or learn knowledge.

Thus, feminist post-structuralism views gender as a social construction which is constructed and is reinforced by discourses (Blaise, 2009; Adriay, 2019a; 2019b). Yelland
(2005) also explains that gender discourse is constructed, reconstructed and negotiated at school. Post-structuralism recommends deconstruction of the dominant gender discourse to construct a more equal gender discourse.

\section{RESEARCH METHODS}

This research is a focused ethnographic research. Focused ethnographic research refers to ethnographic research with a shorter duration (Knoblauch, 2005). This study was conducted in a public kindergarten in Bandung, Indonesia, for 9 weeks with 27 Meetings. The participants were 8 female teachers and 5-6 years old kindergarten children consisted of 40 boys and 46 girls.

The main data collection method is observation with additional interviews. The observations are recorded in field notes. The research uses grounded theory to analyse the data and generate themes. The initial coding produced 189 codes which we focused on 164 codes. The 164 codes then produce several themes. "Toys" is one of the themes which we focus on in this paper. The "toys" theme is divided into three sub-themes which will be explained in the results and discussion. The sub themes in this finding are: (1) Constructing masculinity through superhero toys, (2) Constructing femininity through cooking set toys, (3) Policing gender through toy selection.

\section{RESULT AND DISCUSSION}

\subsection{Constructing Masculinity through Superhero Toys}

The research shows that boys exclude girls through a superhero discourse. Playing a superhero gave a boy a sense of power and domination so that he could block a girl's access to the slide, as depicted in the following field notes,

A girl came to play slide, but a boy wearing a superhero mask would not let her play the slide that he was sitting on. Then, he scared her with his superhero mask so that the girl left annoyed. "Hey what is that?" the researcher asked enthusiastically, the boy was still sitting on the slide.

"Optimus hahaha" he laughed

"Who is Optimus?" asked the researcher

"He got sword to defeat his enemies" he said (Field Notes, March 26, 2018) 


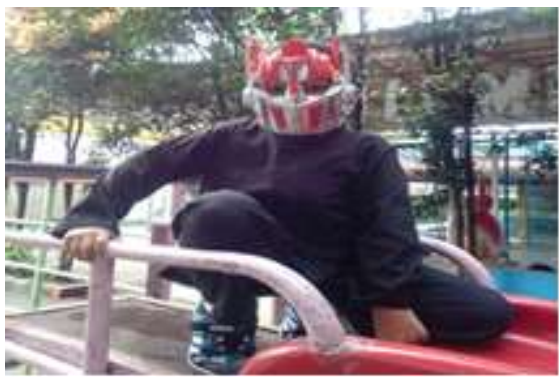

Figure 1 The boy using superhero toys to limit girl's accses

The toy used by the boy is Optimus. Optimus is one of the male heroes who strengthens the superhero discourse. Boys often adopt values of masculinity from superhero discourse (Paechter, 2007; Kilvington \& Wood, 2016) where superheroes are often shown with hypermasculine values like violence and fighting. The boy took hypermasculine value to limit girls' access to playing on the slide. So the girl who wanted to play on the slide choose to leave instead. This is also an example where boys take on the hegemonic masculinity values of control and dominance in public space (Paechter, 2007).

Despite the fact of perpetuating boys' domination over a play space and limiting girls' access to the space, teachers unwittingly strengthened the superhero through the selection of toys for boys, as shown in the following quote from the field notes,

Mrs. Nendeh asked us to take the puzzle on the toys cupboard. Then, she said to the boys, "boys, you play Naruto puzzle with Mrs. Suci. The teacher did not ask the girls to play the puzzle. We, then, joined the boys and had a chat with them while they were playing the puzzle.

"What is this? Naruto?" we asked while handing in a few superheroes pieces of puzzle to the students.

"No, this is Boboboy" Said one of the boys

In the Boboboy puzzle, there are two female superheroes and three male superheroes.

"What's the difference between this and this?" we asked them while pointing out one of the female superheroes and one of the male superheroes.

"This one is male and this one is female" said one of the boys.

"What do you think about female superheroes?" we asked.

"They will die instantly." Then they laughed. (Field Notes, April 2, 2018).

The teacher gave boys more opportunities than girls to play puzzle. We assumed that the Boboboy male superheroes pictures had led the teacher to give the puzzle to the boys instead of the girls. Thus, the puzzle became masculine just because of the superheroes picture.
Superheroes is indeed a medium by which conventional masculinity is reinforced and constructed in boys (Adriany, 2019b).

The superhero discourse in the picture of the puzzle also instills the value of masculinity where boys assume that male superheroes are stronger than female superheroes. Boys who often watch superhero programs are more gender stereotyped in terms of games and activities (Coyne, Linder, Rasmussen, \& Nelson, 2014). The idea is depicted in the boy's comment that implies female superheroes are weak that is why they will die right away. The strong and aggressive masculinity discourse (Adriany, 2019b) seems to determine the boy's comment. This dominant masculinity discourse is often depicted in decades of superheroes stories loved by children, especially boys. Throughout history most superhero characters are male, displaying muscle and strength, while female superheroes are portrayed as facile, selfish, mute and even dead. Female superheroes are also portrayed as a person who is warm, emotional, beautiful, sexy and attractive while the male superhero is muscular, aggressive, threatening, angry and tough (Baker \& Raney, 2007).

The example of event quoted above shows that a selection of toys becomes gendered due to the underlying gender discourse that is strereotypical. The teacher did not realise that the dominant gender discourse had affected the way she selected toys to play by boys or girls. A supposedly gender neutral has become gendered due to the dominant discourse adopted by the teacher without her being aware of it.

\subsection{Constructing Femininity through Cooking Set Toys}

Girls in this research also showed gendered understanding of toys, as quoted below,

"Jesika, who do you like to play with?" we asked a girl

"I like to play with Aisya and Rosa" She answered (they're all girls)

"What kind of play do you do together with your friends?" we asked.

"We pretend play cooking" Said Rosa while looking at us.

"Oh, then, what else do you play? We asked enthusiastically.

"Dolls. Girls play Barbies and pretend play cooking" answered one of the girls

"So, what do the boys play? Asked the researcher

"Boys play robots or cars. Girls play Barbies and pretend play cooking, right? Said Jesika, 
trying to ask their friends assurance. Her friends nodded. (Field Notes, March 28, 2018)

Through selection of toys, girls construct understanding of the meaning of being a girl and their femininities. Domestic chores and family related play is indeed associated to girls' play (Kilvington \& Wood, 2016). This is of course related to the traditionally dominant discourse of gender division of labour, where men's place is in the public sphere which deals with production and economy, while women's place is in the house doing reproductive and social roles. Through gendered selection of toys, girls are taught and socialised to adopt the conventional femininity with traditional gender roles.

\subsection{Policing Gender through Toy Selection}

To make sure a child conforms to his/her gender assigned at birth, teachers strictly demarcated which toys are appropriate for boys and which toys are appropriate for girls. A child who do not conform the his/her gender is policed to the selection of toys. There was one boy in this kindergarten who showed interest in stereotypically girls' toys, whose gender they corrected, so they claimed. A teacher told us the story of this boy.

"When he first started school, he liked girl toys, he liked dresses, played cooking, created a girly toys. We told him eventually that those toys are for girls. Even the parents were asking for Miss Cici and Miss Indi's help to tell Adit that those toys are not for him. Praise be upon God, it was difficult at first as he didn't stop playing with girl toys. He brought a hijab to school, and he fashioned something out of unused table cloth. But with persistent guidance, he eventually understands that they are for girls. It's not that we forbid him to play with all those things, but he had to know that those are girl toys. But my hope (Miss Cici) is that he doesn't go down the wrong way (playing/becoming like a girl)" (Interview with Miss Cici, May 30, 2018).

The quote above depicts how the teacher policed the boy's gender by saying that his selection of toys was inappropriate, since the toys were for girls not boys. The quote also shows how parents and teachers alike police the children's understanding of gender by strengthening the traditional gender discourse. Gender policing is often associated with directing children to the socially appropriate gender identity. Often, the policing is realised in the form of stigmatisation and downgrading the sense of masculinity of the boy who prefer stereotypically feminine toys (Adriany \& Warin, 2014; Paechter, 2007).

\section{CONCLUSION}

The research shows that a dominant gender discourse has affected the way teachers think of which toys are appropriate for boys and which toys are appropriate for girls. Thus, toy selection is gendered. The selection of toys has also become a way to make sure every child conforms to gender identity assigned since he/she was born. Consequently, the children who select traditionally gender inappropriate toys are subject to correction. Parents and teachers need to understand that limiting children's access to a certain kind of toys could mean limiting children's opportunity to learn certain skills by which the toy enhances. can severely limit children's access and space to explore their development. The teachers should also be aware that their selection of toys could result in discrepancy of skills between boys and girls. Thus, we recommend that teachers should equip themselves with egalitarian understanding of gender to promote gender equality in early childhood education.

\section{ACKNOWLEDGMENT}

The researchers would like to thank the Ministry of Research, Technology and Higher Education in Indonesia.

\section{REFERENCES}

Adriany, V. (2013). Gendered power relations within child-centred discourse: An ethnographic study in a kindergarten in Bandung, Indonesia (Phd thesis). Lancaster University, Lancaster, England.

Adriany, V. (2019a). Being a princess: young children's negotiation of femininities in a Kindergarten classroom in Indonesia. Gender and Education, 31(6), 724-741.

Adriany, V. (2019b). 'I don't want to play with the Barbie boy': Understanding Gender-Based Bullying in a Kindergarten in Indonesia. International Journal of Bullying Prevention, 1-9.

Adriany, V., \& Warin, J. (2014). Preschool teachers approaches to care and gender differences within a childcentred pedagogy: Findings from an Indonesian kindergarten. International Journal of Early Years Education: Routledge

Baker, K., \& Raney, A. A. (2007). Equally super?: Gender-role stereotyping of superheroes in children's animated programs. Mass Communication \& Society, 10(1), 25-41.

Blaise, M. (2009). "What a girl wants, what a girl needs": Responding to sex, gender, and sexuality in the 
early childhood classroom. Journal of Research in Childhood Education, 23(4), 450-460.

Burman, E. (2008). Deconstructing Developmental Psychology. New York: Routledge.

Chapman, R. (2016). A case study of gendered play in preschools: how early childhood educators' perceptions of gender influence children's play. Early Child Development and Care, 186(8), 1271-1284.

Cherney, I. D., Kelly-Vance, L., Glover, K. G., Ruane, A. M. Y., \& Ryalls, B. O. (2003). The effects of stereotyped toys and gender on play assessment in children aged 18-47 months. Educational Psychology, 23(1), 95-106.

Coleman, J. M., \& Hong, Y. Y. (2008). Beyond nature and nurture: The influence of lay gender theories on self-stereotyping. Self and Identity, 7(1), 34-53.

Coyne, S. M., Linder, J. R., Rasmussen, E. E., Nelson, D. A., \& Collier, K. M. (2014). It'sa bird! It'sa plane! It'sa gender stereotype!: Longitudinal associations between superhero viewing and gender stereotyped play. Sex Roles, 70(9-10), 416-430.

Early, D. M., Iruka, I. U., Ritchie, S., Barbarin, O. A., Winn, D. M. C., Crawford, G. M., ... \& Bryant, D. M. (2010). How do pre-kindergarteners spend their time? Gender, ethnicity, and income as predictors of experiences in pre-kindergarten classrooms. Early Childhood Research Quarterly, 25(2), 177-193.

Fabes, R. A., Hanish, L. D., \& Martin, C. L. (2003). Children at play: The role of peers in understanding the effects of child care. Child Development, 74(4), 10391043.

Foucault, M. (1982). The subject and power. Critical Inquiry, 8(4), 777-795.

Francis, B. (2010). Gender, toys and learning. Oxford Review of Education, 36(3), 325-344.

Freeman, N. K. (2007). Preschoolers' perceptions of gender appropriate toys and their parents' beliefs about genderized behaviors: Miscommunication, mixed messages, or hidden truths?. Early Childhood Education Journal, 34(5), 357-366.

Hana, L. (2018). Impak Desain Mainan Untuk Anak Pada Kesetaraan Gender. Anlmage Jurnal Studi Kultural.

Kilvington, J., \& Wood, A. (2016). Gender, sex and children's play. Bloomsbury Publishing.
Knoblauch, H. (2005). Focused ethnography. Qualitative Social Research, 6(3).

MacNaughton, G. (2000). Rethinking gender in early childhood education. Sage.

MacNaughton, G. (2005). Doing Foucault in early childhood studies: Applying poststructural ideas. Psychology Press

MacNaughton, G., \& Davis, K. (2009). Discourses of "race" in early childhood: From cognition to power. In "Race" and Early Childhood Education. New York: Palgrave Macmillan.

Martin, B. (2011). Children at Play: Learning Gender in the Early Years. Trentham Books Ltd. Westview House 734 London Road, Oakhill, Stoke-on-Trent, Staffordshire, ST4 5NP, UK.

Osgood, J. (2006). Deconstructing professionalism in early childhood education: Resisting the regulatory gaze. Contemporary Issues in Early Childhood, 7(1), 514.

Paechter, C. (2006, January). Power, knowledge and embodiment in communities of sex/gender practice. Women's Studies International Forum, 29(1), 13-26.

Paechter, C. (2007). Being boys; being girls: learning masculinities and femininities: Learning masculinities and femininities. England: McGraw-Hill Education (UK).

Ryan, S. (2005). Freedom to choose: Examining children's experiences in choice time. Critical Issues In Early Childhood Education, 99-114.

Smith, K. (2014). Discourses of childhood safety: what do children say?. European Early Childhood Education Research Journal, 22(4), 525-537.

Sumsion, J. (2005). Preschool Children's Portrayals of their Male Teacher'In N. Critical Issues In Early Childhood Education, 58.

Walkerdine, V. (1993). Beyond Developmentalism?. Theory \& Psychology, 3(4), 451-469. doi:10.1177/0959354393034004

Wood, E., Desmarais, S., \& Gugula, S. (2002). The impact of parenting experience on gender stereotyped toy play of children. Sex Roles, 47(1), 39-49.

Yelland, N. (2005). Critical Issues In Early Childhood Education. McGraw-Hill Education (UK). 